\title{
Democratic Republic of the Congo: Interim Poverty Reduction Strategy Paper Preparation Status Report
}

Poverty Reduction Strategy Papers (PRSPs) are prepared by member countries in broad consultation with stakeholders and development partners, including the staffs of the World Bank and the IMF. Updated every three years with annual progress reports, they describe the country's macroeconomic, structural, and social policies in support of growth and poverty reduction, as well as associated external financing needs and major sources of financing. This country document for the

Democratic Republic of the Congo, dated June 2004, is being made available on the IMF website by agreement with the member country as a service to users of the IMF website.

To assist the IMF in evaluating the publication policy, reader comments are invited and may be sent by e-mail to publicationpolicy@imf.org.

Copies of this report are available to the public from

International Monetary Fund • Publication Services

$70019^{\text {th }}$ Street, N.W. • Washington, D.C. 20431

Telephone: (202) 623-7430 • Telefax: (202) 623-7201

E-mail: publications@imf.org・Internet: http://www.imf.org

Price: $\$ 15.00$ a copy

\section{International Monetary Fund \\ Washington, D.C.}


Democratic Republic of the Congo

Ministry of Planning

Interministerial Commission on the Implementation of the National Poverty Reduction Strategy (CI-SNLCP)

Steering Committee for the Poverty Reduction Strategy Preparation Process (UPPE-SRP)

Second Progress Report on the I-PRSP Implementation and the Formulation of the Full PRSP June 2003-June 2004 


\section{INTRODUCTION}

1. The government of the Democratic Republic of the Congo (DRC) has been implementing the Interim Poverty Reduction Strategy Paper (I-PRSP) since June 2002. The first PRSP progress report was submitted to the Executive Boards of the IMF and the World Bank in June 2003. Its assessment was positive. This report covers the second year of implementation of the I-PRSP. First, it presents the background and progress achieved in implementing the I-PRSP, and then it discusses the process of preparing the full PRSP, along with its constraints. The revised timetable and budget for the process are also presented.

\section{I-PRSP IMPLEMENTATION AND PROGRESS}

2. The DRC's I-PRSP is based on three fundamental pillars, namely: peace and good governance, which are considered to be the essential condition for the strategy to succeed (pillar 1); stabilization and pro-poor growth (pillar 2); and support for grassroots initiatives (pillar 3). At the same time, the I-PRSP distinguishes three distinct phases of economic development: a stabilization phase (2001-02), a reconstruction phase (2002-05), and a sustained development phase (starting in 2005). From the political and economic point of view, the implementation of the IPRSP in the 2003-2004 period took place against a much more favorable backdrop than that of the 2002-2003 period.

\section{A. Political Aspects}

3. In the 2003-2004 period, the DRC made considerable progress in the area of peace and good governance. After difficult negotiations in Pretoria (South Africa), the Global and Inclusive Agreement was signed, the implementation of which enabled the formation of a Government of National Unity, inaugurated on June 30, 2003. With the help of the international community, the government undertook to achieve the reunification of the country, the consolidation of peace, good governance, and the organization of free, transparent, and democratic elections (pillar 1 of the PRSP).

4. Specifically, the efforts of the Government of National Unity have led to the reunification of the DRC, the consolidation of the peace process despite the recent events in the eastern part of the country, and the withdrawal of almost all foreign troops. In addition, the creation of the political and administrative institutions in the provinces, the security services, police force, and an integrated army, has progressed significantly. Corruption, predatory practices, and money laundering 
were targeted by draft laws submitted by the government to Parliament, which are scheduled to be voted on in July 2004. Similarly, with the aim of consolidating peace, the government has developed the Disarmament, Demobilization, and Reintegration (DDR) program.

5. The Parliament that resulted from the Global and Inclusive Agreement meets regularly and is gradually establishing the laws needed for the smooth functioning of the Republic. Civic institutions are in place and are beginning to provide support for the democratic system and the defense of individual liberties. Even though the continued existence of parallel administrations in the reunified provinces slows the process, it should be noted that this cannot halt the progress that is under way.

6. In conformity with the Transitional Constitution's provisions relating to the organization of the elections, the government published the plan outlining the stages and actions to be taken to prepare the DRC for the elections in 2005. The promulgation of the law on the census and the establishment of the independent electoral commission is an integral part of this roadmap. By the same token, the legal provisions on the functioning of political parties are being drawn up.

\section{B. Economic Aspects}

7. With support from the international community, in particular that of the World Bank and the International Monetary Fund, the government has tirelessly pursued its economic, financial and structural adjustment policies aimed at stabilizing the macroeconomic situation and the creation of a climate conducive to private sectorled development as set out in the government economic program (PEG).

8. Performance under the PEG has been broadly satisfactory. The improvement in economic management and in the business climate has restored confidence and improved the attractiveness of investment. As a result, for the first time in 13 years real GDP growth became positive in 2002 (3.5 percent) and accelerated to 5.6 percent in 2003 . For 2004, a rate of 6.3 percent is forecast. The slowdown in inflation, begun in 2001, continued. From a rate of 135 percent in 2001, it declined to 15.8 percent in 2002 and fell further to 4.4 percent in 2003. Thus, in 2003 the DRC moved from the stabilization phase to the reconstruction phase, as envisaged in the I-PRSP.

9. The government diligently continued its policy of fiscal consolidation, based on reforms designed to improve revenue mobilization and expenditure management. In this regard, the establishment of the new expenditure procedures, from commitment to payment, and the harmonization and functional classifications of the budget nomenclature improve the process of tracking government expenditure, and in particular pro-poor spending. Other reforms designed to enhance expenditure management have been set in motion. This applies to the adoption of double-entry accounting framework by the Ministries of Finance and the Budget, and the 
reorganization of the procedures for paying civil servants on the basis of the recommendations of the external audit of the payroll system. A comprehensive reform of the civil service has been initiated.

10. Further, the government has undertaken reforms designed to rehabilitate various key sectors of the economy. The completion of the modernization of the legal framework of public enterprises and institutions, and a strategic audit of the Public Enterprise Council (Conseil Supérieur du Portefeuille) are under way, as well as the restructuring of the COHYDRO oil distribution company and the GECAMINES mining company. Also, the Government has published the new Mining, Forestry, Investment and Labor Codes. In the context of these reforms, commercial courts have also been set up. Finally, the government has completed the plans for restructuring the DRC's banking system and has initiated the restructuring of public enterprises.

11. As of June 2003, the government established the Pro-poor Spending Monitoring Committee, tasked with monitoring the execution and evaluating the impact of propoor spending. The committee has just begun the process of identifying the projects and the procurement to use the balance available as at April 30, 2004 in the HIPC resources account, which is approximately US\$75 million. In this regard, it must be stressed that pro-poor spending reached 1.5 percent of GDP in 2003. The Government's target is to raise this to over 6.5 percent in 2004. The independence of the committee should guarantee the poverty reduction strategy's transparency and credibility.

12. It is worth noting that the DRC has considerably improved its economic and trade relations with the rest of the world. In 2003, the external current account showed a stronger improvement than expected due to an increase in exports and net transfers. The upswing in exports is essentially attributable to wood and diamonds, with the latter benefiting from the application of the Kimberley process. This enabled a larger share of diamond exports to be routed through official channels.

13. The DRC's economic and financial management has been positively assessed by its multilateral partners (World Bank, IMF), bilateral partners (Paris Club), and private partners (London Club, Kinshasa Club). Consequently, the DRC reached the enhanced HIPC initiative decision point on July 23, 2003. Similarly, the bilateral talks following the debt consolidation signed with the Paris Club members on September 13, 2002 were finalized. Finally, the DRC has submitted a request to the World Bank to obtain the financial resources that would enable it to settle its arrears with the London Club creditors.

14. The launching of the reconstruction and investment projects contained in the Multisectoral Rehabilitation and Reconstruction Program (PMURR) have helped improve infrastructure and social and economic services. Combined with the effective implementation of the projects through the UCOP project coordination 
unit, these reconstruction and reunification projects are expected to impact positively on the DRC's poor.

\section{Administrative Aspects and Grassroots Initiatives}

15. Concerning administrative governance and the strategy of support for grassroots initiatives, the government benefits from the support of its bilateral and multilateral partners just as in the case of political and economic governance. The World Bank (WB), the African Development Bank (AfDB), the European Union (EU), the United Nations Development Programme (UNDP), and various bilateral donors (for example, Belgium, Canada, France; and the United Kingdom) are joining forces to support the reforms undertaken in this area. This also applies to capacity-building, voluntary retirement, and social security.

16. With over 80 percent of the population employed in the agricultural sector, the DRC has developed, in the context of the PMURR and with the support of the AfDB, the project to support the rehabilitation of the agricultural sector (PARSAR). This will provide a renewed impetus to the agricultural and rural sector to ensure food security and poverty reduction.

17. With respect to grassroots initiatives (pillar 3 of the I-PRSP), specific recommended actions to institutionalize and consolidate them have not been fully realized. As a result, the establishment of the National Poverty Observatory and the National Poverty Reduction Charter has been delayed. Studies financed by the AfDB, concerning the planning, organization, and orientation of grassroots initiatives have just started.

18. The government has also continued its efforts in the health sector, in particular in combating the HIV/AIDS virus, by starting the Multisectoral Anti-AIDS program, continuing the national program for combating malaria (distribution of treated mosquito nets, etc.), tuberculosis, and other pandemics. With the help of USAID, the rehabilitation of rural health centers under the Rural Health Project (SANRU) has also continued. The health minister adopted the national health improvement plan, increasing the number of health areas from 312 to 515 . This increase should result in a broader coverage of, and increased access to, those health centers. The World Bank has completed the paper on the social protection strategy, the execution of which has started with a view to reducing the vulnerability of the poorest segments of the population.

19. Additionally, the minister of education, with the support of all education partners, approved the national "Education for all by 2015" plan. Similarly, the support of UNICEF and UNDP has led to the improvement of the social programs and the establishment of the Millennium Development Goals (MDG) monitoring program. By the same token, the government set up the program for the promotion of the role 
of women in society, the aim of which is to address the gender gap in the various sectors of national life.

\section{PREPARATION OF THE FULL PRSP}

20. The timetable has had to be adjusted to accommodate the scope of the reforms and the need to strengthen the institutional framework for preparing the PRSP. Nevertheless, the government is adhering to its target of producing the full PRSP in August 2005. This deadline is critical for the country to reach the HIPC initiative completion point in August 2006. The DRC government is certainly aware of the fact that this timetable is very tight and risks affecting the quality of the PRSP. However, given the positive effects expected from reaching the HIPC initiative completion point, it is well worth trying to keep the original deadline.

\section{A. Strengthening the Institutional Framework}

21. To adapt the institutional framework to the composition of the Government of National Unity and, taking into account the amount of work to be done following the reunification of the country, Decree 03/047 dated December 18, 2003 defines the composition of the Interministerial Commission on the Implementation of the National Poverty Reduction Strategy that was established by Decree 055/2002 dated April 12, 2002. This decree also creates the Steering Committee for the Poverty Reduction Strategy Preparation and Implementation Process (UPPE-SRP), and the technical committees at the national and provincial levels.

22. The following actions were taken on the basis of Decree 03/047:

- Appointment of the national coordinator and deputy coordinator of the Steering Committee for the PRSP process;

- The number of members of the technical committee was increased from 10 to 25 , to ensure broad representation;

- Appointment of the coordinators and deputy coordinators of the provincial technical committees;

- The recruitment of the entities tasked with executing the participatory consultations through public notices in the media; and

- The recruitment of four permanent national experts to strengthen the UPPE's technical work, as well as an administrative and financial manager.

23. In addition, the group of donors and lenders involved in the PRSP process designated focal points, namely the Department of International Development (DFID) and the United Nations Development Programme (UNDP), which are acting as interface between donors and lenders and the UPPE. The group also provided the Steering Committee with an international expert in social analysis tasked with ensuring that the participatory consultation process runs smoothly. 


\section{B. Participatory Consultations}

24. The preparatory stages for the participatory consultations have ended. Training manuals have been prepared for the provincial committees, the bodies tasked with carrying out the consultations, the members of the technical committees (both national and provincial), and the sectoral and thematic groups.

25. The Participatory Poverty Assessment (PPA) methodology was selected in the course of the international workshop that was held in Kinshasa in January 2004. At that workshop, all partners acknowledged the superiority of the PPA over alternative methodologies, in particular, the one put forward by the Research and Technical Exchange Group (GRET).

26. Nevertheless, the implementation of the training and the participatory consultations is behind schedule, due to administrative weakness and delays in obtaining funds from the members of the PRSP support group. These delays have also affected the first payment to the 10 entities responsible for the participatory consultations, ${ }^{1}$ and have created a significant lag in the execution of the roadmap.

\section{Preparation of the Sectoral and Thematic Strategies}

27. To improve the sectoral and thematic strategies of the full PRSP, 16 groups have been created. They are composed of experts from the member ministries of the Interministerial Commission on the Implementation of the National Poverty Reduction Strategy, civil society, the private enterprise sector, the unions, the universities, and research centers ${ }^{2}$.

1 The assignment of these entities per province is as follows: (1) Caritas Développement, for the Equateur and Orientale provinces; (2) National Council of Nongovernmental Development Organizations (CNONGD), for the Katanga province; (3) Bureau d'Etudes, de Recherche et de Consulting International (BERCI) (a market and opinion research institute), for the city of Kinshasa; (4) Antenne de Formation à Distance, for the Bandundu province; (5) Amis de la Santé for the Bas-Congo province, (6) Confederation of Small and Medium Enterprises of the Congo (Copemeco), for the Kasaï Oriental province; (7) Facilitas Consulting, for the Kasaï Occidental province; (8) Service for the Reinforcement of Assistance to Grassroots Communities in Central Africa (SERACOB), for Sud-Kivu; (9) Bureau d'études et d'expertises pour le développement (B.E.E.D.) (a local development research consultancy), for Nord-Kivu province; and (10) Congolese Initiative for the Rescue of the People of Goma (ICG), for the province of Maniema.

2 These thematic groups are: (1) Peace, political governance, administrative and judiciary reforms; (2) Macro-economic framework and program harmonization; (3) Fiscal and economic reforms; (4) Private sector, wealth creation, employment, micro finance and the banking sector; (5) Agriculture and rural development; (6) Education; (7) HIV/AIDS and malaria; (8) Urban poverty; (9) Gender, vulnerable groups and social security; (10) Environment; (11) Grassroots initiatives and basic services; (12) Community, culture and 
28. The sectoral and thematic inventories prepared by these groups are in the process of being discussed within the technical committee. They provide an overview of the problems, strategies, and actions in the major sectors and the themes they cover. After finalization by a consultant specialized in sectoral analysis, they will be sent for analysis and approval to the Interministerial Commission for Monitoring the National Poverty Reduction Strategy. To ensure the accuracy and effectiveness of the proposed strategies, they will then be subject to sectoral and thematic participatory consultations with the relevant key partners, before they are included in the final formulation of the full PRSP strategies. In this process, the groups will use the results of similar studies conducted by bilateral and multilateral partners.

\section{Statistical Analyses and Survey}

29. The UPPE has awarded the outsourcing of the consumption budget survey (1-2-3) to the National Statistics Institute (INS) for the collection of data on employment, household consumption, and the informal sector. With financing from the Program for Mobilizing National Poverty Reduction Capacity in the DRC (CAPNAT), the questionnaire and the methodology have already been finalized and the survey is currently under way in Kinshasa. Its expansion across the whole nation, which is managed jointly by the UPPE and the INS, is partially funded by the AfDB. Through the intervention of the statistics expert and three members of the methodological group of the technical committee, the UPPE is closely involved in the operations.

30. Assuming that the planned human and financial resources will be available, the timetable for executing the whole survey includes the following stages (details are shown in the schedule in the annex):

- The consumption budget survey (1-2-3) will take place in Kinshasa from April through September 2004. The data processing will take place between June and December 2004;

- The survey of the other provinces will take place within the same timeframe (June-December 2004);

- The data processing for all the provinces will take place from January through March $2005^{3}$;

- The final report on all surveys (both qualitative and quantitative) should be available in May 2005;

- The data from the participatory consultations (qualitative data) and from the household budget survey (quantitative data) will be incorporated into the

new technologies; (13) Transport and communication infrastructure; (14) Mines; (15) Energy; and (16) Methodology.

${ }^{3}$ The time needed for data processing will be shorter as experience will have been gained with the Kinshasa exercise. 
PRSP in June-July 2005. They will be used to improve the statistical basis of the poverty profile and the selection of the full PRSP strategies.

\section{E. Capacity Building}

31. The process as a whole requires highly qualified domestic and international human resources. A training program for the main bodies of the UPPE has been prepared, i.e. for the technical committees at the national and provincial levels, for the thematic and sectoral groups, and for the bodies responsible for the participatory consultations. The training will take place in June 2004. Financing for this activity, in particular from DFID, the UNDP, the AfDB, and the EU, will have to be made available promptly to ensure that the training can take place in a timely manner. In addition, various training missions for the UPPE experts in poverty analysis, sectoral strategies, and data processing are planned. The hiring of international experts is also envisaged.

\section{F. Strengthening the Internal Partnership}

32. The internal partnership set up by the government is proceeding as planned. The number of civil society and private enterprise organizations in the CT-SRP (Poverty Reduction Strategy Technical Committee) has been increased to strengthen their involvement in the process. This applies particularly to the National Council of Development NGOs (CNONGD), CARITAS-Développement, and the Federation of Enterprises in the Congo (Fédération des Entreprises du Congo - FEC). Many of these organizations were selected to hold sectoral and thematic participatory consultations, both in Kinshasa and in the provinces.

\section{G. Dissemination and Internalization of the Process}

33. The campaign publicizing the I-PRSP and the process of preparing the full PRSP has been carried out by means of posters and through the media since July 2003. The UPPE hired a consultant responsible for disseminating the I-PRSP and monitoring and assessing the roadmap of this process. The dissemination campaign has also been carried out by means of printing and distributing the I-PRSP. A monthly information bulletin on the PRSP is being prepared. It will be distributed to all partners.

34. At the government level, internalization of the process has specifically involved integrating the objective of poverty reduction into the President's program speech delivered to the Transitional Parliament in July 2003, and the participation of the President and his team in the PRSP process. Parliament, for its part, has appointed a parliamentary working group to monitor PRSP preparation and to participate in all activities organized in the context of the participatory process. A member of Parliament took part in the training workshop-seminar on the participatory approach 
to PRSP preparation, organized by the AfDB in Dakar from January 26 through 29, 2004.

\section{H. Budget Process}

Due primarily to the expansion of the Commission for Implementing the National Poverty Reduction Strategy and to the reunification of the country, the overall budget for implementing the process of preparing the full PRSP was revised upwards from US\$5,820,910 to US\$8,325,137. The functional breakdown is as follows:

- Support for institutional framework

$$
\begin{array}{r}
1,321,160 \\
2,376,897 \\
1,850,000 \\
480,800 \\
339,240 \\
113,390 \\
343,650 \\
1,500,000
\end{array}
$$

- Drawing up of the PRSP

\section{K. Challenges and Constraints}

35. Given its post-conflict situation and the vastness of its territory, the DRC faces particular challenges and constraints, the most significant of which are summarized as follows:

(i) The risk of resurgence of conflict, particularly in the eastern part of the country, and interruptions in the peace process could compromise the agreed implementation timetable;

(ii) The delay in providing the Steering Committee for the PRSP Preparation Process (UPPE-SRP) with the needed resources, human and financial, could cause slippages in the timetable;

(iii) The lack of a coherent synergy between the PRSP preparation process and that of other government sectoral programs on the one hand, and between the latter and the other partners' intervention strategies on the other, poses a major risk to the efficacy and quality of the full PRSP. It could even affect the efficiency of its implementation; and

(iv) The political pressures inherent in the pre-electoral period could affect the process. Attempts to influence its course, to 
direct its content, and even to use it as an instrument of political propaganda cannot be totally ruled out.

\section{CONCLUSION}

36. The environment for implementing the I-PRSP in the 2003-2004 period improved considerably over that of the first year. Following the installation of the transitional government, the weaknesses noted on the political front are in the process of gradually being overcome. The government continues to carry out the PEG, including the structural reform agenda, which has had noticeable positive effects on the macroeconomic environment. Reforms have also been undertaken to enhance the quality of governance and access by the poor to basic social services.

37. The involvement of the development partners, civil society, and the private sector has been strengthened, resulting in better participation. Nevertheless, the process has been delayed by the slowness of the provision of human and financial resources. This has led to an adjustment of the timetable and the budget. Persistence of this delay may cause slippage in the execution of the programmed activities.

Kinshasa, June 2004

Steering Committee for the Poverty Reduction Strategy Preparation Process (UPPE-SRP) 
-12 -

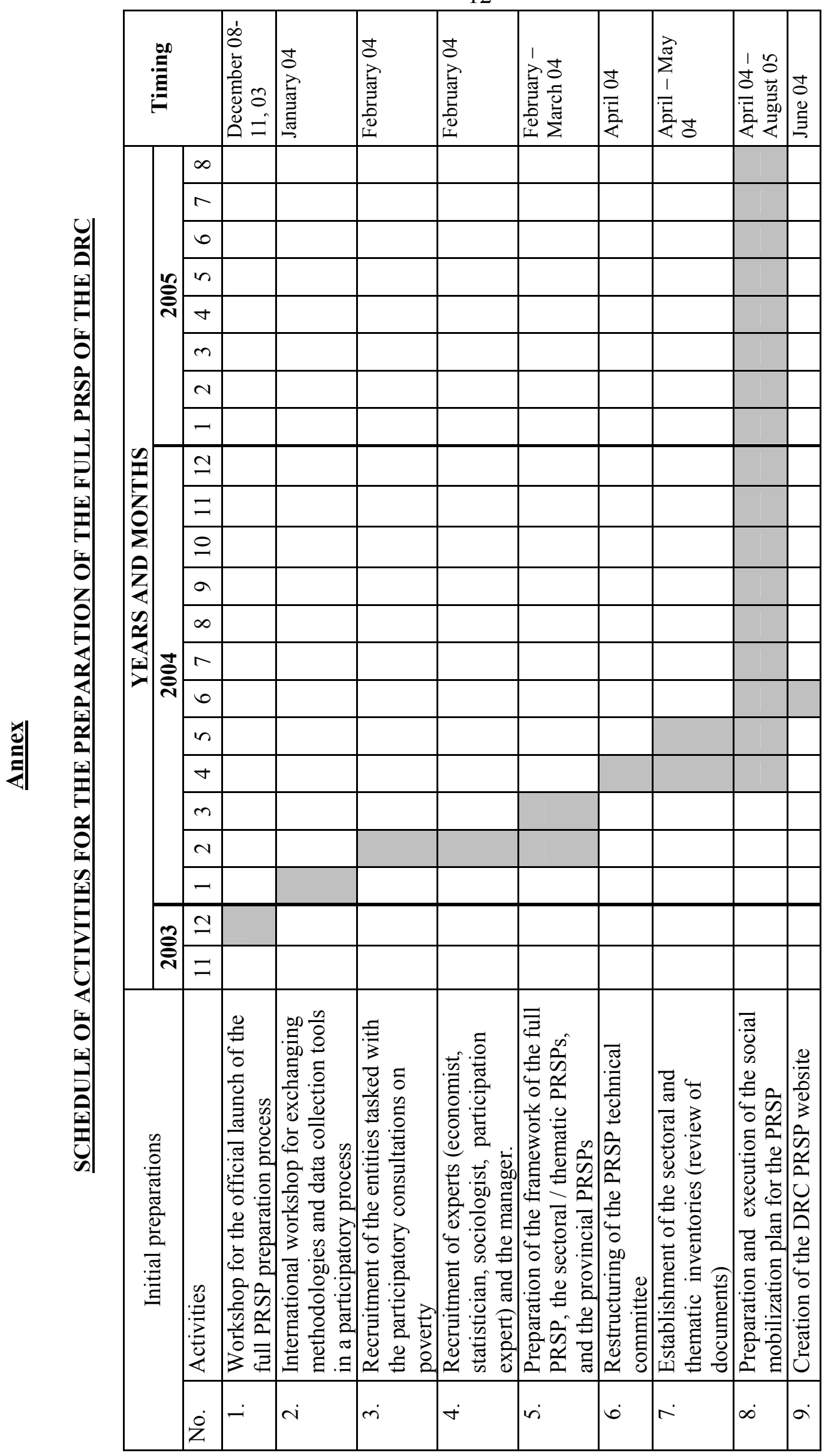


-13 -

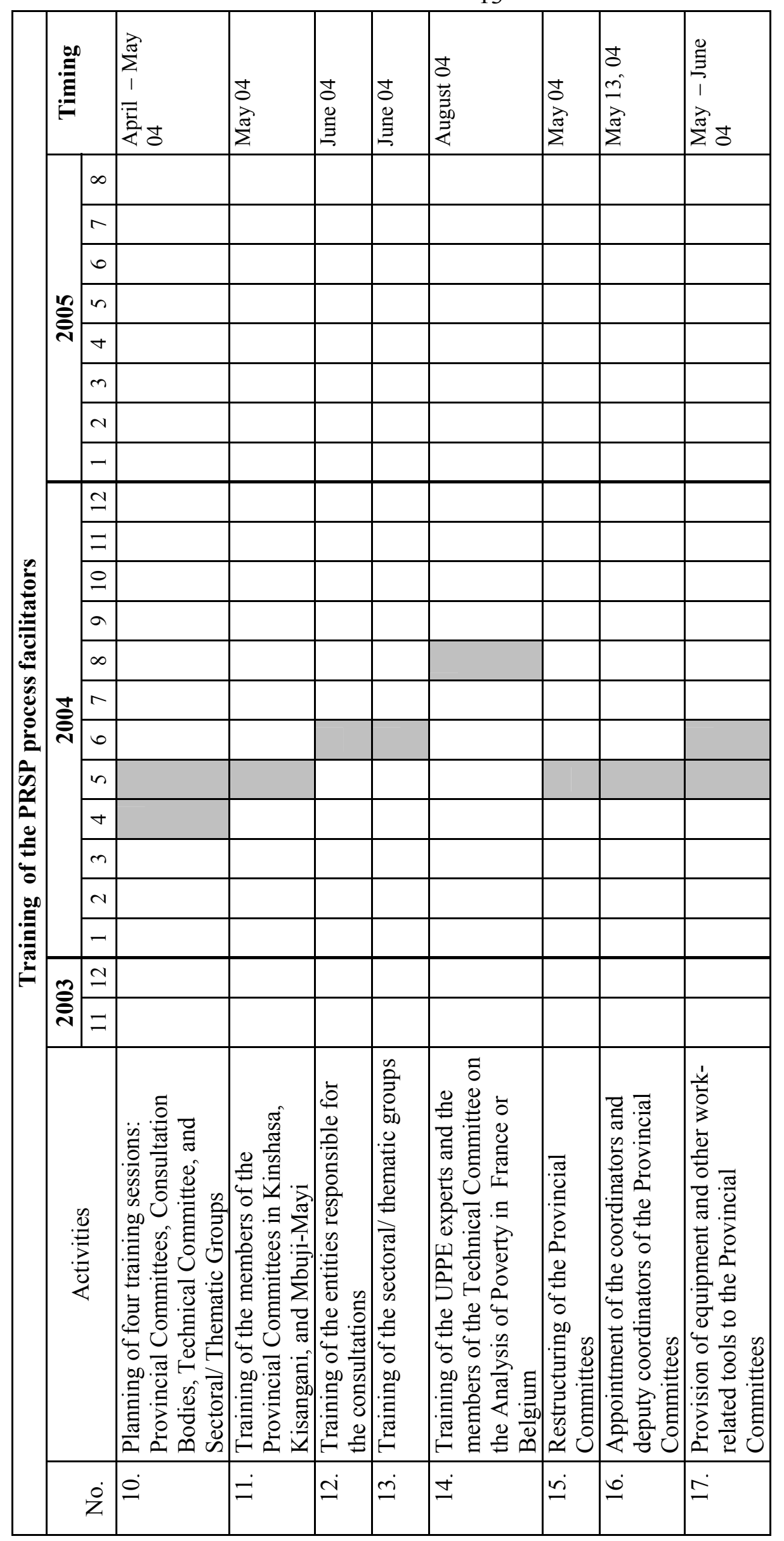


-14 -

\begin{tabular}{|c|c|c|c|c|c|c|c|c|c|}
\hline & 野 & & $\begin{array}{l}\Xi \\
\Xi \\
\Xi \\
\Xi\end{array}$ & $\begin{array}{l} \pm \\
0 \\
2 \\
\Xi \\
1 \\
1 \\
0 \\
\vdots \\
\vdots\end{array}$ & 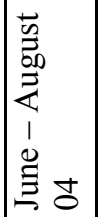 & 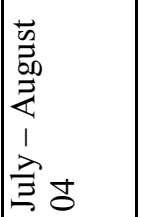 & 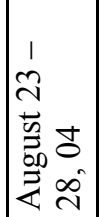 & 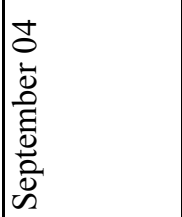 & 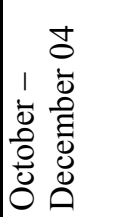 \\
\hline & & $\infty$ & & & & & & & \\
\hline & & - & & & & & & & \\
\hline & & 0 & & & & & & & \\
\hline & & $n$ & & & & & & & \\
\hline & ন્స & $\nabla$ & & & & & & & \\
\hline & & $m$ & & & & & & & \\
\hline & & $N$ & & & & & & & \\
\hline & & - & & & & & & & \\
\hline & & $\simeq$ & & & & & & & \\
\hline ق. & & $=$ & & & & & & & \\
\hline$\stackrel{\Xi}{\Xi}$ & & 으 & & & & & & & \\
\hline & & $a$ & & & & & & & \\
\hline 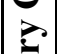 & & $\infty$ & & & & & & & \\
\hline$\stackrel{\Xi}{\tilde{I}}$ & $\Xi$ & $r$ & & & & & & & \\
\hline 苞 & & 6 & & & & & & & \\
\hline 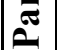 & & in & & & & & & & \\
\hline$\stackrel{0}{0}$ & & $\nabla$ & & & & & & & \\
\hline$\vec{z}$ & & $m$ & & & & & & & \\
\hline 0 & & $N$ & & & & & & & \\
\hline$\Xi$ & & - & & & & & & & \\
\hline $\bar{\Xi}$ & $\approx$ & $\simeq$ & & & & & & & \\
\hline نे & సิ & $=$ & & & & & & & \\
\hline & & 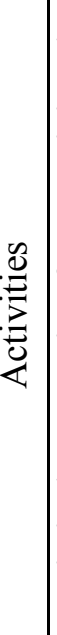 & 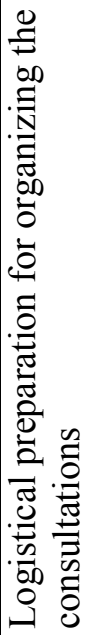 & 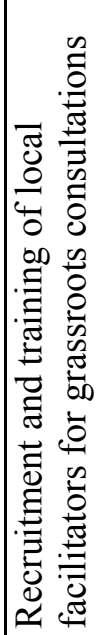 & 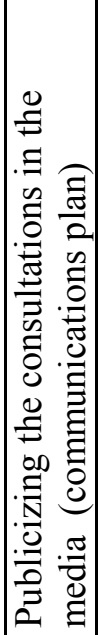 & 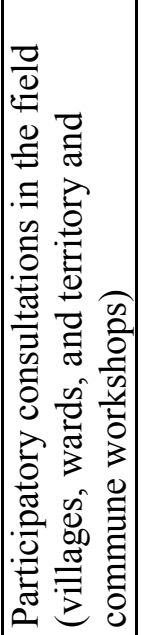 & 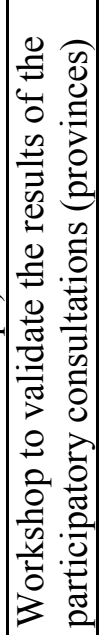 & 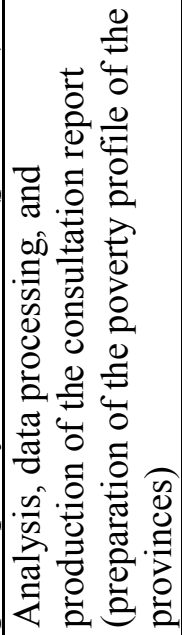 & 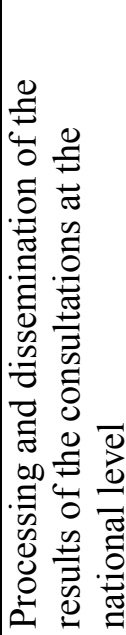 \\
\hline & & $\dot{0}$ & $\stackrel{\infty}{\infty}$ & $\stackrel{0}{2}$ & $\dot{\sim}$ & $\dot{\vec{\lambda}}$ & 시 & $\ddot{\lambda}$ & ¿் \\
\hline
\end{tabular}




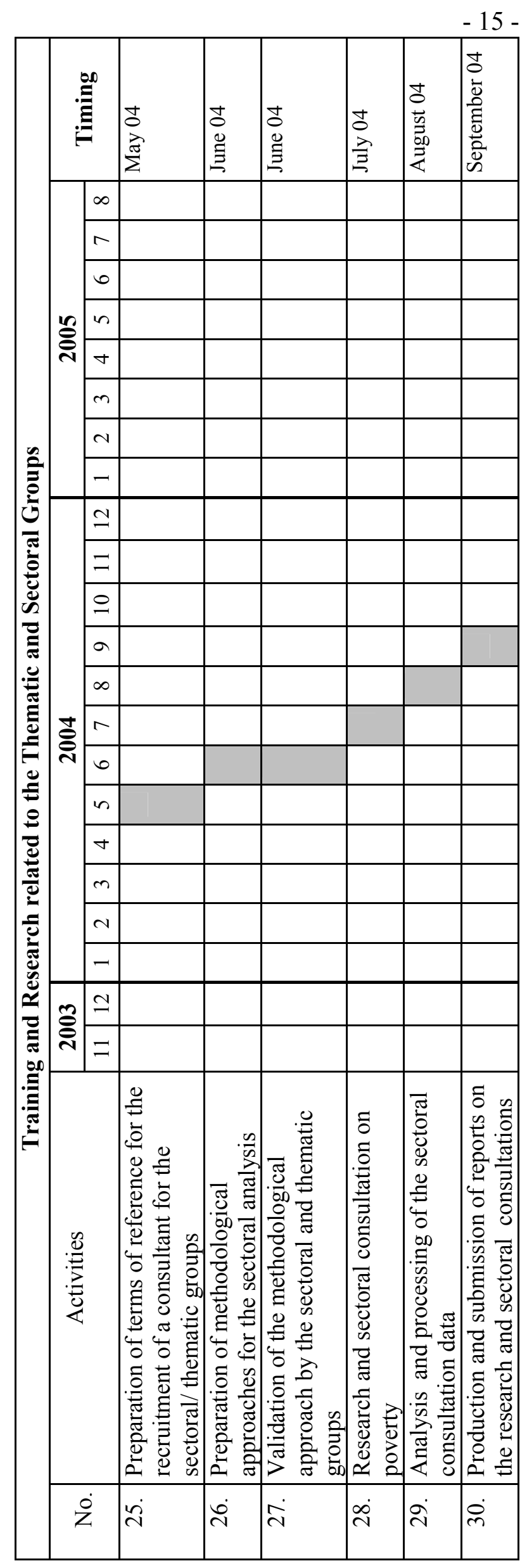


$-16-$

\begin{tabular}{|c|c|c|c|c|c|c|c|c|c|c|c|c|c|c|}
\hline & 吕 & & 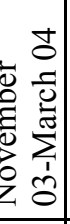 & 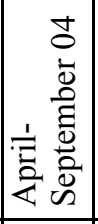 & 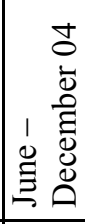 & 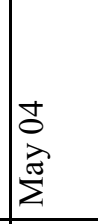 & 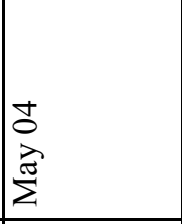 & $\begin{array}{l}\text { ठ } \\
0 \\
\Xi \\
\Xi\end{array}$ & $\begin{array}{l}\text { ठ } \\
\Phi \\
\Xi \\
\Xi\end{array}$ & 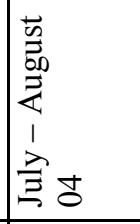 & 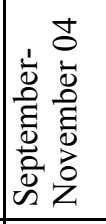 & 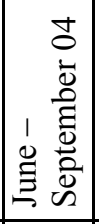 & 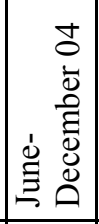 & 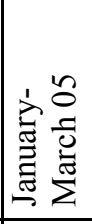 \\
\hline & & $\infty$ & & & & & & & & & & & & \\
\hline & & $r$ & & & & & & & & & & & & \\
\hline & & 0 & & & & & & & & & & & & \\
\hline & $\approx$ & $n$ & & & & & & & & & & & & \\
\hline & త్స & $\nabla$ & & & & & & & & & & & & \\
\hline & & $m$ & & & & & & & & & & & & \\
\hline & & $\sim$ & & & & & & & & & & & & \\
\hline & & - & & & & & & & & & & & & \\
\hline & & $\simeq$ & & & & & & & & & & & & \\
\hline & & $=$ & & & & & & & & & & & & \\
\hline & & $\underline{0}$ & & & & & & & & & & & & \\
\hline & & $a$ & & & & & & & & & & & & \\
\hline & & $\infty$ & & & & & & & & & & & & \\
\hline & $\overrightarrow{0}$ & $r$ & & & & & & & & & & & & \\
\hline & নิ & 6 & & & & & & & & & & & & \\
\hline & & $n$ & & & & & & & & & & & & \\
\hline & & $\nabla$ & & & & & & & & & & & & \\
\hline & & $m$ & & & & & & & & & & & & \\
\hline & & $\sim$ & & & & & & & & & & & & \\
\hline & & - & & & & & & & & & & & & \\
\hline & $m$ & $\simeq$ & & & & & & & & & & & & \\
\hline & ন্য & $\exists$ & & & & & & & & & & & & \\
\hline 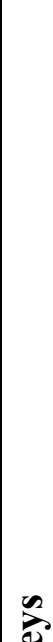 & : & & 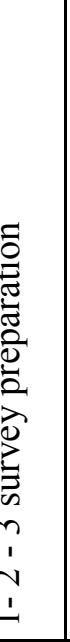 & 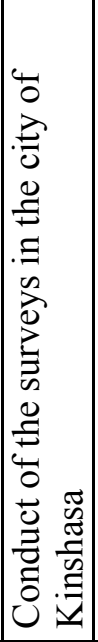 & 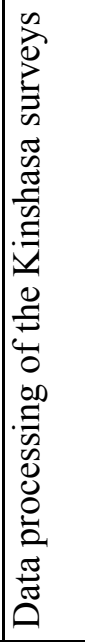 & 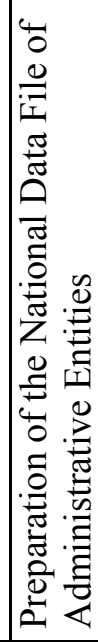 & 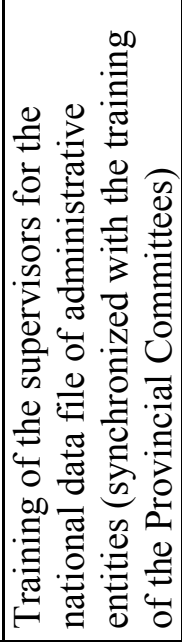 & 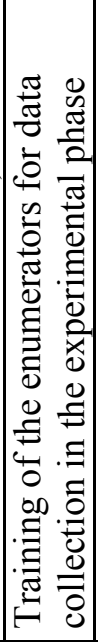 & 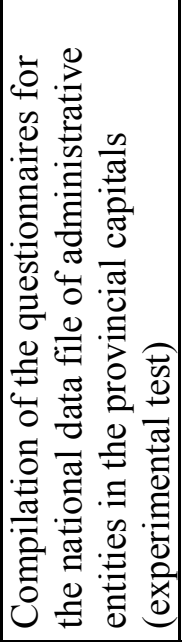 & 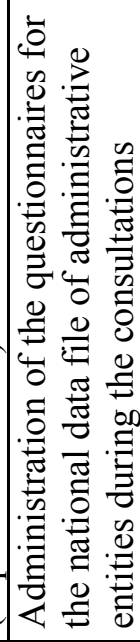 & 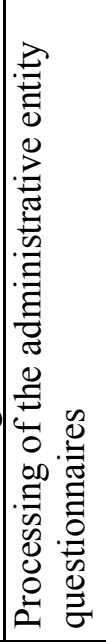 & 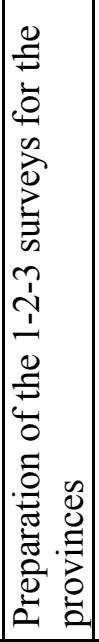 & 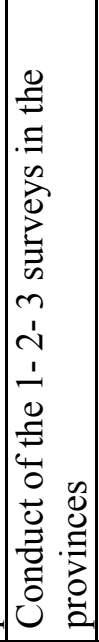 & 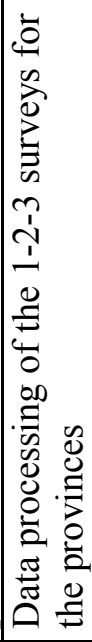 \\
\hline$\stackrel{E}{E}$ & $\dot{0}$ & $\dot{m}$ & $\dot{n}$ & mi & $\dot{m}$ & mं & $\ddot{n}$ & $\dot{ల}^{\dot{0}}$ & in & $\dot{\infty}$ & ले & $\dot{q}$ & $\dot{\nabla}$ & ส่ \\
\hline
\end{tabular}




\begin{tabular}{|c|c|c|c|c|c|c|c|c|}
\hline 曷 & 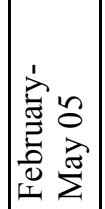 & 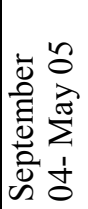 & 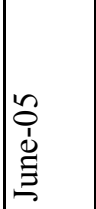 & $\mid$ & $\begin{array}{l}0 \\
0 \\
3 \\
3\end{array}$ & 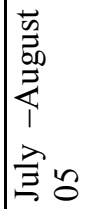 & 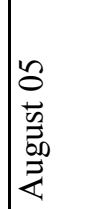 & 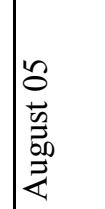 \\
\hline$\infty$ & & & & & & & & \\
\hline r & & & & & & & & \\
\hline 0 & & & & & & & & \\
\hline$\because n$ & & & & & & & & \\
\hline ते| & & & & & & & & \\
\hline$m$ & & & & & & & & \\
\hline$\sim$ & & & & & & & & \\
\hline- & & & & & & & & \\
\hline I & & & & & & & & \\
\hline$=$ & & & & & & & & \\
\hline 은 & & & & & & & & \\
\hline$\sigma$ & & & & & & & & \\
\hline$\infty$ & & & & & & & & \\
\hline \pm 1 & & & & & & & & \\
\hline$\pi$ & & & & & & & & \\
\hline in & & & & & & & & \\
\hline$\nabla$ & & & & & & & & \\
\hline$m$ & & & & & & & & \\
\hline$\sim$ & & & & & & & & \\
\hline- & & & & & & & & \\
\hline$\bumpeq=$ & & & & & & & & \\
\hline$\sim=$ & & & & & & & & \\
\hline 峞 & 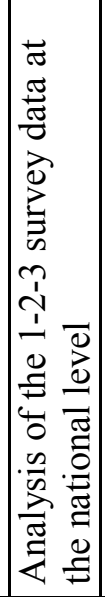 & 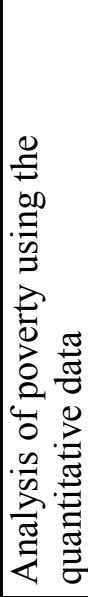 & 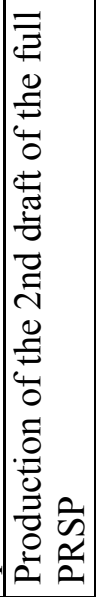 & 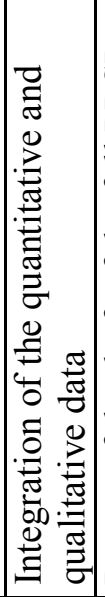 & 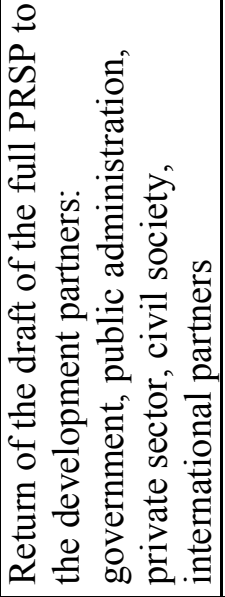 & 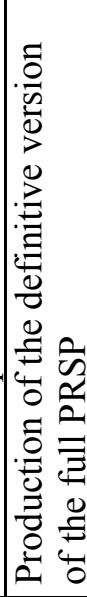 & 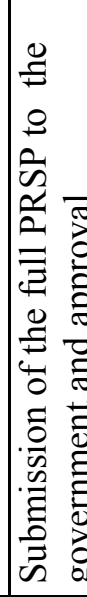 & 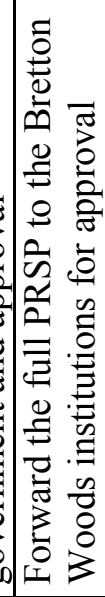 \\
\hline & $q$ & 过 & $\dot{q}$ & f́ & F & $\dot{\leftrightarrow}$ & $q$ & in \\
\hline
\end{tabular}



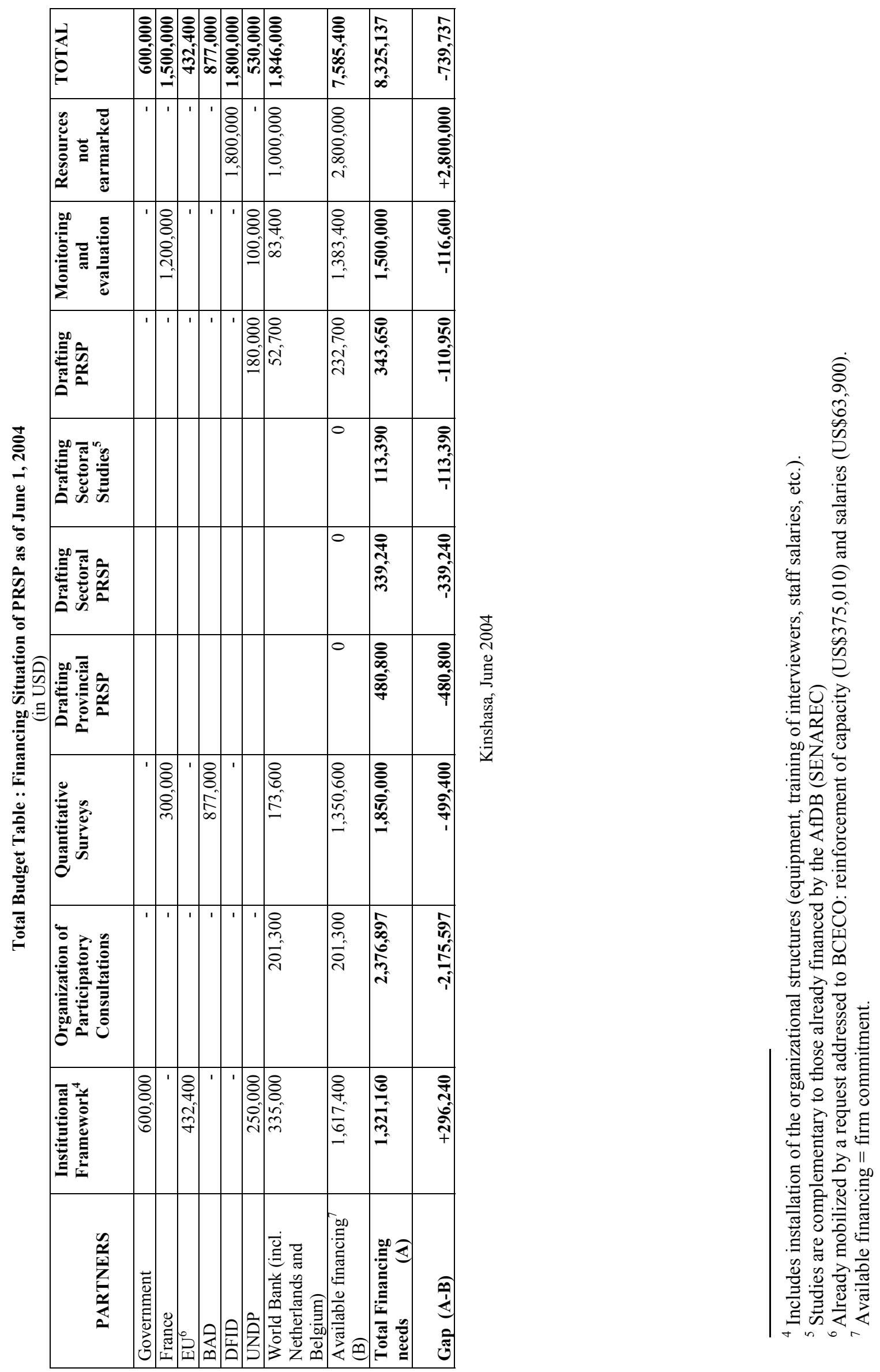